\title{
Heat shock and tumor necrosis factor- $\alpha$ induce apoptosis in bovine preimplantation embryos through a caspase-9-dependent mechanism
}

\author{
Bárbara Loureiro ${ }^{1,2}$, Amber Mary Brad ${ }^{1}$ and Peter James Hansen ${ }^{1}$ \\ ${ }^{1}$ Department of Animal Sciences, University of Florida, PO Box 110910, Gainesville, Florida 32611-0910, USA and \\ ${ }^{2}$ Departamento de Medicina Veterinária, Universidade Federal Rural de Pernambuco, Recife-PE, Brazil
}

Correspondence should be addressed to P J Hansen; Email: hansen@animal.ufl.edu

\begin{abstract}
Heat shock and tumor necrosis factor- $\alpha$ (TNF- $\alpha$ ) induce apoptosis through different mechanisms, with heat shock acting to cause mitochondrial depolarization and caspase-9 activation, while TNF- $\alpha$ acts through a receptor-mediated process to activate caspase-8. In some cells, however, TNF- $\alpha$ can also cause mitochondrial depolarization and caspase-9 activation. In the present study, we tested the hypothesis that heat shock at $41^{\circ} \mathrm{C}$ and TNF- $\alpha$ induce apoptosis in bovine preimplantation embryos through a caspase-9-dependent mechanism. Treatment of embryos with either heat shock $\left(41^{\circ} \mathrm{C}\right)$ or TNF- $\alpha$ increased the proportion of blastomeres that were TUNEL positive and the proportion of embryos exhibiting elevated caspase-9 activity. Furthermore, the caspase-9 inhibitor, z-LEHD-fmk, blocked the increase in TUNEL-positive nuclei caused by both heat shock and TNF- $\alpha$. For embryos at day 6 after insemination, for example, the percent of blastomeres positive for TUNEL was 3.6\% for control embryos, $\mathbf{1 1 . 1} \%$ for embryos cultured at $41{ }^{\circ} \mathrm{C}$, and $15.1 \%$ for embryos cultured with $10 \mathrm{ng} / \mathrm{ml} \mathrm{TNF}-\alpha$. In the presence of z-LEHD-fmk, the percent of cells positive for TUNEL was $3.7 \%$ for control embryos, $6.1 \%$ for embryos cultured at $41{ }^{\circ} \mathrm{C}$, and $8 \%$ for embryos cultured with $10 \mathrm{ng} / \mathrm{ml} \mathrm{TNF-} \alpha$. Although TNF- $\alpha$ did not cause a measurable increase in caspase-8 activity, there was a tendency $(P=0.07)$ for treatment of embryos with z-IETD-fmk, an inhibitor of caspase-8, to partly reduce the magnitude of the increase in TUNEL-positive cells caused by TNF- $\alpha$. The percent of cells that were TUNEL positive was increased by TNF- $\alpha$ from 9.7 to $19.7 \%$ in the absence of inhibitor and from 13.0 to $15.6 \%$ in the presence of z-IETD-fmk. Results indicate that induction of apoptosis by both heat shock and TNF- $\alpha$ involve activation of caspase-9-dependent pathways. It is likely that TNF- $\alpha$ also activates apoptotic pathways involving caspase-8 but that the degree of activation is small and caspase-9-dependent pathways are required for full activation of apoptosis.
\end{abstract}

Reproduction (2007) 133 1129-1137

\section{Introduction}

Programmed cell death or apoptosis is developmentally regulated during preimplantation development. In the bovine embryo, there are few morphological signs of apoptosis during early cleavage stages of development (Byrne et al. 1999, Matwee et al. 2000). While the maturing oocyte can undergo apoptosis, at least in response to heat shock (Roth \& Hansen 2004), the twocell embryo is refractory to induction of apoptosis caused by heat shock, tumor necrosis factor- $\alpha$ (TNF- $\alpha$ ), and arsenic (Krininger et al. 2002, Paula-Lopes \& Hansen 2002a, Soto et al. 2003a). Based on results using heat shock, capacity for induced apoptosis becomes acquired between the 8- and 16-cell stages (Paula-Lopes \& Hansen 2002a).
The consequences of apoptosis may also depend upon stage of development. Induction of apoptosis is a major cause for the reduced oocyte competence for fertilization and development caused by heat shock (Roth \& Hansen 2004). In contrast, limited apoptosis in response to heat shock may be beneficial by day 4 of development, because addition of the caspase inhibitor, z-DEVD-fmk, exacerbated deleterious effects of heat shock on development to the blastocyst stage (Paula-Lopes \& Hansen 2002b).

Heat shock induces apoptosis by activating the mitochondrial or intrinsic pathway for induction of apoptosis (Mirkes \& Little 2000, Yuen et al. 2000, Little \& Mirkes 2002, Beere 2004, Bettaieb \& Averil-Bates 2005). This pathway involves mitochondrial depolarization, release of cytochrome $c$ and apoptosis inducing 
factor, and formation of a large multimeric complex termed the apoptosome composed of cytochrome $c$ and apoptosis-activating factor-1 (Apaf-1) that activates procaspase-9. As a result, procaspase-9 is converted to caspase-9, which in turn leads to activation of caspase-3, cleavage of poly (ADP-ribose) polymerase (PARP), activation of caspase-activated DNase, and fragmentation of DNA (Beere 2004, Sprick \& Walczak 2004). TNF- $\alpha$ induces apoptosis through activation of the receptormediated or extrinsic pathway. In this pathway, TNF- $\alpha$ complexes with its receptor to stimulate formation of the death-inducing signaling complex (DISC) and caspase-8 activation, which in turn causes direct activation of downstream caspases such as caspase-3 (Sprick \& Walczak 2004). There is increasing evidence that induction of apoptosis by TNF- $\alpha$ can also involve the mitochondrial pathway (Sprick \& Walczak 2004). In particular, caspase-8 can cleave the Bcl-2 family protein, $\mathrm{Bid}$, to generate a $\mathrm{C}$-terminal fragment that translocates to the mitochondria to cause depolarization and cytochrome $c$ release (Luo et al. 1998). There is also evidence for direct cleavage of procaspase- 9 by caspase- 8 (McDonnell et al. 2003). It is thought that activation of caspase-9 may be important for pro-apoptotic signaling by TNF- $\alpha$ and other ligands activating the instrinsic pathway in cases where either DISC formation is reduced or amounts of anti-apoptotic proteins such as heat-shock protein 70 or inhibitor of apoptosis are high, so that amounts of activated caspase-8 are insufficient to induce caspase-3 without involvement of mitochondrial apoptogenic activity (Sprick \& Walczak 2004). Examples of cells where activation by TNF- $\alpha$ and related ligands depends upon caspase-9 include L9292 cells (Yuen et al. 2000), T-lymphocytes (Sun et al. 2002), colon cancer cells (Ozoren \& El-Deiry 2002), pro-B-lymphoma cells (McDonnell et al. 2003), and hepatocytes (Ozoren et al. 2000, Imao et al. 2006).

The goal of the present study was to determine the importance of caspase- 9 for apoptosis in preimplantation embryos exposed to heat shock and TNF- $\alpha$. Heat shock was used because effects of elevated temperature on embryonic survival have been implicated in the infertility experienced by lactating cows during heat stress (Hansen \& Aréchiga 1999). Actions of TNF- $\alpha$ were of interest because this cytokine may be a contributor to the reduced fertility associated with mastitis (Hansen et al. 2004).

\section{Materials and Methods \\ Materials}

The media HEPES-Tyrodes lactate (HEPES-TL), in vitro fertilization (IVF)-TL, and Sperm-TL were purchased from Caisson (Sugar City, ID, USA) and used to prepare HEPESTyrodes albumin lactate pyruvate (TALP), IVF-TALP, and Sperm-TALP as previously described (Parrish et al. 1986).
Oocyte collection medium (OCM) was tissue culture medium-199 (TCM-199) with Hank's salts without phenol red (Hyclone, Logan, UT, USA) supplemented with $2 \%$ $(\mathrm{v} / \mathrm{v})$ bovine steer serum (Pel-Freez, Rogers, AR, USA) containing $2 \mathrm{U} / \mathrm{ml}$ heparin, $100 \mathrm{U} / \mathrm{ml}$ penicillin-G, $0.1 \mathrm{mg} / \mathrm{ml}$ streptomycin, and $1 \mathrm{mM}$ glutamine. Oocyte maturation medium (OMM) was TCM-199 (Invitrogen) with Earle's salts supplemented with $10 \%(\mathrm{v} / \mathrm{v})$ bovine steer serum, $2 \mu \mathrm{g} / \mathrm{ml}$ estradiol $17-\beta, 20 \mu \mathrm{g} / \mathrm{ml}$ bovine FSH (Folltropin-V; Vetrepharm Canada, London, ON, USA), $22 \mu \mathrm{g} / \mathrm{ml}$ sodium pyruvate, $50 \mu \mathrm{g} / \mathrm{ml}$ gentamicin sulfate, and $1 \mathrm{mM}$ glutamine. Percoll was from Amersham Pharmacia Biotech.

Potassium simplex optimized medium (KSOM) that contained $1 \mathrm{mg} / \mathrm{ml}$ BSA was obtained from Caisson. Essentially fatty-acid free BSA was from Sigma. On the day of use, KSOM was modified for bovine embryos to produce KSOM-BE2 by adding additional BSA $(3 \mathrm{mg} / \mathrm{ml})$, non-essential amino acids, and gentamicin (final concentration, $5 \mu \mathrm{g} / \mathrm{ml}$ ) as described elsewhere (Soto et al. 2003b).

Murine recombinant TNF- $\alpha$ was purchased from United States Biological (Swampscott, MA, USA). The TNF- $\alpha$ was dissolved in $5 \mathrm{mM}$ Tris- $\mathrm{HCl}(\mathrm{pH} \mathrm{8.0)}$ and then diluted 1:1000 in culture medium, so that the final concentration of Tris- $\mathrm{HCl}$ was $5 \mu \mathrm{M}$. In all experiments, control medium also contained $5 \mu \mathrm{M}$ Tris. The caspase-8 inhibitor, z-IETD-fmk, and caspase-9 inhibitor, z-LEHDfmk, were obtained from R\&D Systems (Minneapolis, $M N$, USA). These molecules are peptide-based competitive irreversible inhibitors containing $\mathrm{P} 1$ of the $\mathrm{P} 1-\mathrm{P} 1^{\prime}$ cleavage site $(\mathrm{P} 1=\mathrm{D})$ and with caspase activity conferred by the amino acid at P4 (Garcia-Calvo et al. 1998). Inhibitors were dissolved in DMSO and then diluted in KSOM-BE2 to a concentration of $100 \mu \mathrm{M}$ and with a final concentration of $0.5 \%(\mathrm{v} / \mathrm{v})$ DMSO. Control media contained an equivalent volume of DMSO.

The in situ Cell Death Detection Kit (rhodamine) was obtained from Roche Diagnostics Corporation. Polyvinylpyrrolidone (PVP) was purchased from Eastman Kodak and RQ1 RNase-free DNase was from Promega. Prolong Antifade Kit was obtained from Molecular Probes (Eugene, OR, USA). Caspalux $8-L_{1} D_{2}$ and CaspaLux $9-M_{1} D_{2}$ were purchased from Oncolmmunin (Gaithersburg, MD, USA). Hoescht 33342 was purchased from Sigma-Aldrich. All other reagents were purchased from Sigma or Fisher Scientific.

\section{In vitro production of embryos}

Embryo production was performed as previously described (Soto et al. 2003b). Briefly, cumulus oocyte complexes (COCs) were obtained by slicing 2-10 mm follicles on the surface of ovaries (a mixture of beef and dairy cattle) obtained from Central Beef Packing Co. (Center Hill, FL, USA). Those COCs with at least one complete layer of compact cumulus cells were washed 
twice in OCM, placed in groups of 10 in $50 \mu$ microdrops of OMM overlaid with mineral oil and matured for $20-22 \mathrm{~h}$ at $38.5{ }^{\circ} \mathrm{C}$ in an atmosphere of $5 \%(\mathrm{v} / \mathrm{v}) \mathrm{CO}_{2}$ in humidified air. Matured COCs were washed once in HEPES-TALP and transferred in groups of 30 to four-well plates containing $600 \mu \mathrm{I}$ IVF-TALP and $25 \mu \mathrm{l}$ of a solution of $0.5 \mathrm{mM}$ penicillamine, $0.25 \mathrm{mM}$ hypotaurine, and $25 \mu \mathrm{M}$ epinephrine in $0.9 \%(\mathrm{w} / \mathrm{v}) \mathrm{NaCl}$ and fertilized with $\sim 1 \times 10^{6}$ Percoll-purified spermatozoa from a pool of frozen-thawed semen from three bulls. After 20-22 $\mathrm{h}$ at $38.5{ }^{\circ} \mathrm{C}$ in an atmosphere of $5 \%(\mathrm{v} / \mathrm{v}) \mathrm{CO}_{2}$ in humidified air, putative zygotes were removed from fertilization wells, denuded of cumulus cells by vortex in HEPESTALP, and placed in groups of 30 in $50 \mu \mathrm{l}$ microdrops of KSOM-BE2. Putative zygotes were cultured at $38.5^{\circ} \mathrm{C}$ in an atmosphere of $5 \%(\mathrm{v} / \mathrm{v}) \mathrm{CO}_{2}$ in humidified air until selected for treatment at days 4,5 , and 6 after insemination. At these times, embryos $\geq 16$ cells (day 4), morulae (day 5), and compact morulae (solid spherical mass of blastomeres) or early blastocysts (day 6) were harvested from culture and utilized as required for the specific experimental design. One culture plate for each replication was kept as an undisturbed control. The percent of oocytes that became blastocysts at day 8 after insemination averaged $27 \pm 1.4 \%$.

\section{TUNEL assay}

Embryos were washed twice in $50 \mu \mathrm{l}$ microdrops of $10 \mathrm{mM} \mathrm{KPO}_{4}(\mathrm{pH} 7.4)$ containing $0.9 \%(\mathrm{w} / \mathrm{v}) \mathrm{NaCl}(\mathrm{PBS})$ and $1 \mathrm{mg} / \mathrm{ml}$ PVP (PBS-PVP) by transferring the embryos from microdrop to microdrop. Zona pellucida-intact embryos were fixed in a $50 \mu \mathrm{l}$ microdrop of $4 \%(\mathrm{w} / \mathrm{v})$ paraformaldehyde in PBS for 15 min at room temperature, washed twice in PBS-PVP, and stored in $600 \mu \mathrm{l}$ PBS-PVP at $4{ }^{\circ} \mathrm{C}$ until the time of assay. All steps of the TUNEL assay were conducted using microdrops in a humidified box.

On the day of the TUNEL assay, embryos were transferred to a $50 \mu \mathrm{l}$ microdrop of PBS-PVP and then permeabilized in $0.1 \%(\mathrm{v} / \mathrm{v})$ Triton X-100 containing $0.1 \%(\mathrm{w} / \mathrm{v})$ sodium citrate for $10 \mathrm{~min}$ at room temperature. Positive controls for the TUNEL assay were incubated in $50 \mu \mathrm{l}$ RQ1 RNase-free DNase $(50 \mathrm{U} / \mathrm{ml})$ at $37^{\circ} \mathrm{C}$ in the dark for $1 \mathrm{~h}$. Positive controls and treated embryos were washed in PBS-PVP and incubated with $25 \mu \mathrm{l}$ TUNEL reaction mixture (containing TMR redconjugated dUTP and the enzyme terminal deoxynucleotidyl transferase as prepared by and following the guidelines of the manufacturer) for $1 \mathrm{~h}$ at $37^{\circ} \mathrm{C}$ in the dark. Negative controls were incubated in the absence of terminal deoxynucleotidyl transferase. Embryos were washed thrice in PBS-PVP and incubated in a $25 \mu \mathrm{l}$ microdrop of the Hoescht $33342(1 \mu \mathrm{g} / \mathrm{ml})$ for $15 \mathrm{~min}$ in the dark. After three additional washes in PBS-PVP to remove excess Hoescht 33 342, embryos were mounted on $10 \%(\mathrm{w} / \mathrm{v})$ poly-L-lysine coated slides using 3-4 $\mathrm{\mu l}$ microdrops of Antifade, and coverslips were placed on the slides. Labeling was observed using a Zeiss Axioplan 2 epifluorescence microscope (Zeiss, Göttingen, Germany). Each embryo was analyzed for total cell number (blue nuclei) and TUNEL-positive blastomeres (red nuclei) with DAPI and rhodamine filters respectively, using a 20x objective. Digital images were acquired using AxioVision software (Zeiss) and a highresolution black and white Zeiss AxioCam MRm digital camera.

\section{Caspase-8 and -9 activity}

Caspalux $8-L_{1} D_{2}$ and CaspaLux $9-M_{1} D_{2}$ are caspase substrates for caspase-8 and caspase- 9 respectively that are doubly labeled with a fluoroprobe that is quenched until cleavage by caspase. Cleaved substrate produces green fluorescence. To measure caspase activity, embryos were removed from culture medium and washed thrice in $50 \mu \mathrm{l}$ microdrops of prewarmed HEPES-TALP. Embryos were incubated in groups in $25 \mu \mathrm{l}$ microdrops of $5 \mu \mathrm{M}$ Caspalux $8-\mathrm{L}_{1} \mathrm{D}_{2}$ or CaspaLux 9- $M_{1} D_{2}$ HEPES-TALP at room temperature for $1 \mathrm{~h}$ in the dark. Following incubation, embryos were washed four times in $50 \mu \mathrm{l}$ microdrops of prewarmed HEPES-TALP and placed in two-well slides with $80 \mu \mathrm{l}$ HEPES-TALP. Caspase activity was evaluated using a Zeiss Axioplan 2 fluorescence microscope with a 10X objective and FITC filter. Digital images were acquired using AxioVision software (Zeiss) and a high-resolution black and white Zeiss AxioCam MRm digital camera. Embryos were classified based on the fluorescence intensity as low caspase activity (none or a few fluorescent cells), medium caspase activity (less than half of the cells fluorescent), or high caspase activity (more than half of the cells fluorescent).

\section{Experiments}

\section{Effect of caspase-9 inhibitor on induction of apoptosis by heat shock and TNF- $\alpha$ at various stages of development}

The experiment was designed with a $3 \times 2 \times 3$ factorial arrangement of treatments to determine whether heat shock and TNF- $\alpha$ induce apoptosis at various stages or development and, if so, whether induction of apoptosis could be blocked with the caspase-9 inhibitor, z-LEHDfmk. Main effects were stage of development (days 4, 5, or 6 after insemination), z-LEHD-fmk ( \pm ), and treatment $\left(38.5,41\right.$, or $\left.38.5^{\circ} \mathrm{C}+\mathrm{TNF}-\alpha\right)$. Embryos were collected on days 4, 5, and 6 after insemination and randomly transferred in groups of 7-14 to a fresh $25 \mu \mathrm{l}$ microdrop of KSOM-BE2 containing $100 \mu \mathrm{M}$ z-LEHD-fmk or an equivalent amount of DMSO $(0.5 \%$, $(\mathrm{v} / \mathrm{v}))$. Moreover, microdrops contained either $10 \mathrm{ng} / \mathrm{ml} \mathrm{TNF}-\alpha$ or vehicle (5 $\mu \mathrm{M}$ Tris- $\mathrm{HCl}, \mathrm{pH}$ 8.0). Embryos were then cultured at 
either $38.5^{\circ} \mathrm{C}$ for $24 \mathrm{~h}$ or, for heat-shocked embryos, $41{ }^{\circ} \mathrm{C}$ for $15 \mathrm{~h}$ followed by $38.5^{\circ} \mathrm{C}$ for $9 \mathrm{~h}$. At $24 \mathrm{~h}$ after initiation of treatment, embryos were fixed and stored in PBS-PVP at $4{ }^{\circ} \mathrm{C}$ until analysis by TUNEL assay. The experiment was replicated 4-5 times for each day (26-47 embryos per treatment).

\section{Effects of different concentrations of the caspase-9 inhibitor Z-LEHD-fmk on apoptotic responses of embryos to TNF- $\alpha$}

The experiment was designed as a $2 \times 4$ factorial with main effects of TNF- $\alpha(0$ or $10 \mathrm{ng} / \mathrm{ml})$ and z-LEHD-fmk $(0,1,10$, or $100 \mu \mathrm{M})$. Morulae and blastocysts were collected at day 6 after insemination and were cultured in groups of $6-8$ in $25 \mu \mathrm{l}$ microdrops of KSOM-BE2 for $24 \mathrm{~h}$ in the presence of different concentrations of the inhibitor $z$-LEHD-fmk $\pm 10 \mathrm{ng} / \mathrm{ml} \mathrm{TNF-} \alpha$; the final concentration of Tris- $\mathrm{HCl}$ ( $\mathrm{pH}$ 8.0) was $5 \mu \mathrm{M}$ in all microdrops and the final concentration of DMSO was $0.5 \%(\mathrm{v} / \mathrm{v})$ in all microdrops. After $24 \mathrm{~h}$ at $38.5^{\circ} \mathrm{C}$, embryos were washed, fixed, and stored in PBS-PVP at $4{ }^{\circ} \mathrm{C}$ until analysis by TUNEL. The experiment was replicated four times (20-28 embryos/treatment).

\section{Induction of caspase-9 activity by heat shock}

The experiment was designed with a $2 \times 2$ factorial arrangement of treatments to determine whether heat shock increases caspase-9 activity and whether z-LEHDfmk blocks this increase. Embryos at the morula or blastocyst stage were collected at day 6 after insemination and transferred in groups of 4-7 to a new $25 \mu \mathrm{l}$ microdrop of KSOM-BE2 containing $100 \mu \mathrm{M}$ z-LEHDfmk or DMSO vehicle. Embryos were then cultured at either $38.5^{\circ} \mathrm{C}$ for $24 \mathrm{~h}$ or $41^{\circ} \mathrm{C}$ for $15 \mathrm{~h}$ followed by $38.5^{\circ} \mathrm{C}$ for $9 \mathrm{~h}$. At the end of heat shock, embryos were washed thrice in $50 \mu \mathrm{l}$ microdrops of prewarmed HEPESTALP and then subjected to caspase-9 assay using $5 \mu \mathrm{M}$ CaspaLux $9-M_{1} D_{2}$ as described previously. The experiment was replicated five times using 23-26 embryos per treatment.

\section{Time-course of caspase- 9 activation by TNF- $\alpha$}

The experiment was designed with a $2 \times 5$ factorial arrangement of treatments to determine whether TNF- $\alpha$ increases caspase- 9 activity at various times after exposure to TNF- $\alpha$. Embryos at the morula or blastocyst stage were collected at day 6 after insemination and transferred in groups of 3-7 to a new microdrop of $25 \mu \mathrm{l}$ KSOM-BE2 containing $10 \mathrm{ng} / \mathrm{ml} \mathrm{TNF-} \alpha$ or an equivalent amount of Tris- $\mathrm{HCl}$ vehicle. Embryos were cultured at $38.5^{\circ} \mathrm{C}$ for $3,6,9,12$, or $15 \mathrm{~h}$, harvested, washed thrice in $50 \mu \mathrm{l}$ microdrops of prewarmed HEPES-TALP, and subjected to the caspase- 9 assay. The experiment was replicated eight times using 37-39 embryos per treatment.

\section{Induction of caspase-8 activity by TNF- $\alpha$}

The experiment was designed with a $2 \times 2$ factorial arrangement of treatments to determine whether TNF- $\alpha$ increases caspase- 8 activity and whether z-IETD-fmk blocks this increase. Embryos at the morula were collected at day 5 after insemination and transferred in groups of 5-11 to a new $25 \mu \mathrm{l}$ microdrop of KSOM-BE2 containing $100 \mu \mathrm{M} z$-IETD-fmk or DMSO vehicle, with either $10 \mathrm{ng} / \mathrm{ml}$ TNF- $\alpha$ or vehicle $(5 \mu \mathrm{M}$ Tris-HCl, $\mathrm{pH}$ 8.0). Embryos were cultured at $38.5^{\circ} \mathrm{C}$ for $24 \mathrm{~h}$ in an atmosphere of $5 \% \mathrm{CO}_{2}$. At the end of treatment, embryos were washed thrice in $50 \mu \mathrm{l}$ microdrops of prewarmed HEPES-TALP and then subjected to the caspase-8 assay using $5 \mu \mathrm{M}$ CaspaLux $8-\mathrm{L}_{1} \mathrm{D}_{2}$ as described previously. The experiment was replicated four times using 14-22 embryos per treatment.

\section{Effect of caspase-8 inhibition on induction of apoptosis by $T N F-\alpha$}

The experiment was designed with a $2 \times 2$ factorial arrangement of treatments to determine whether the caspase-8 inhibitor, z-IETD-fmk, blocks the apoptotic effects of TNF- $\alpha$. Morulae were collected on day 5 after insemination and randomly transferred in groups of 5-9 to a fresh $25 \mu \mathrm{l}$ microdrop of KSOM-BE2 containing $100 \mu \mathrm{M}$ z-IETD-fmk or an equivalent amount of DMSO $(0.5 \%,(\mathrm{v} / \mathrm{v}))$, with either $10 \mathrm{ng} / \mathrm{ml} \mathrm{TNF}-\alpha$ or vehicle $(5 \mu \mathrm{M}$ Tris- $\mathrm{HCl}, \mathrm{pH}$ 8.0). Embryos were cultured at $38.5^{\circ} \mathrm{C}$ for $24 \mathrm{~h}$. At the end of the treatments, embryos were fixed and stored in PBS-PVP at $4{ }^{\circ} \mathrm{C}$ until analysis by TUNEL assay. The experiment was replicated four times (30-35 embryos per treatment).

\section{Statistical analysis}

Data on percentage of cells that were TUNEL positive and fluorescent intensity were analyzed by least-squares analysis of variance using the General Linear Models procedure of SAS (SAS for Windows, Version 9.0, Cary, NC, USA). Percentage data were transformed by arcsin transformation before analysis. The mathematical model included main effects and all interactions. Replicate was considered as a random effect and other main effects were considered fixed. Tests of significance were made using error terms determined by calculation of expected mean squares. All values reported are least-squares means \pm S.E.M. Probability values for percentage data are based on analysis of arcsin-transformed data, while least-squares means are from analysis of untransformed data. Categorical data regarding the percent of embryos classified as having low, medium, or high caspase-9 
activity were analyzed by the CATMOD procedure of SAS using main effects and all interactions.

\section{Results}

\section{Effect of caspase-9 inhibitor on induction of apoptosis by heat shock and TNF- $\alpha$ at various stages of development}

Representative images of TUNEL labeling are shown in Fig. 1 and least-squares means \pm S.E.M. for percentage of blastomeres labeled as TUNEL positive are shown in Fig. 2. Heat shock at $41{ }^{\circ} \mathrm{C}$ for $15 \mathrm{~h}$ and incubation with TNF- $\alpha$ for $24 \mathrm{~h}$ increased the percentage of TUNEL-positive cells in control embryos at all days examined (days 4, 5, and 6) when compared with embryos cultured at $38.5{ }^{\circ} \mathrm{C}$ for $24 \mathrm{~h}$. However, induction of apoptosis by both stimuli was blocked by the presence of the caspase- 9 inhibitor, z-LEHD-fmk (treatment $P<0.001$; inhibitor, $P<0.01$; treatment $X$ inhibitor; $P<0.05)$. There was no effect of day after insemination or interactions with day (Fig. 2).

\section{Effects of different concentrations of z-LEHD-fmk on apoptotic responses to $T N F-\alpha$}

As shown in Fig. 3, addition of $10 \mathrm{ng} / \mathrm{ml} \mathrm{TNF}-\alpha$ to culture medium increased the percentage of TUNEL-positive cells of day 6 embryos. This increase was blocked by z-LEHD-fmk at all concentrations tested (1, 10, and $100 \mu \mathrm{M}$; TNF- $\alpha \times$ inhibitor; $P<0.05)$.

\section{Induction of caspase-9 activity by heat shock}

Representative images of caspase-9 activity in embryos as affected by heat shock and z-LEHD-fmk are shown in Fig. 4, while the proportion of embryos classified as having low, medium, or high caspase activity are shown in Fig. 5. Exposure of embryos to $41^{\circ} \mathrm{C}$ increased the proportion of embryos classified as having medium and high caspase- 9 activity and this increase was blocked by z-LEHD-fmk (treatment $P<0.05$; inhibitor $P<0.001$ ).

\section{Time-course of caspase- 9 activation by TNF- $\alpha$}

Representative images of caspase-9 activity in embryos as affected by TNF- $\alpha$ are shown in Fig. 6, while the proportion of embryos classified as having low, medium, or high caspase activity are shown in Fig. 7. Treatment with $10 \mathrm{ng} / \mathrm{ml}$ TNF- $\alpha$ increased the proportion of embryos classified as having medium or high caspase activity at all time points except at $3 \mathrm{~h}$ after addition (treatment, $P<0.05$; time, $P<0.01$ ).

\section{Induction of caspase-8 activity by TNF- $\alpha$}

There was no significant effect of TNF- $\alpha$ or the inhibitor z-IETD-fmk on the proportion of embryos classified as having low, medium, or high caspase-8 activity (Fig. 8).

\section{Effect of caspase-8 inhibition on induction of apoptosis by $T N F-\alpha$}

Least-squares means \pm S.E.M. for percentage of blastomeres labeled as TUNEL positive are shown in Fig. 9. Treatment of embryos with TNF- $\alpha$ for $24 \mathrm{~h}$ increased the percentage of cells labeled TUNEL positive. Moreover, induction of apoptosis by TNF- $\alpha$ was reduced (although not completely blocked) by the caspase-8 inhibitor z-IETD-fmk (treatment, $P<0.05$; treatment $\times$ inhibitor; $P=0.07$ ).

\section{Discussion}

Apoptosis has an important role in the survival of the preimplantation embryo. While excessive activation of the apoptotic process is likely to lead to embryonic demise, limited apoptosis in response to stress can facilitate embryonic survival (Paula-Lopes \& Hansen $2002 b$ ). In the current report, experimental evidence is presented to demonstrate that activation of caspase- 9
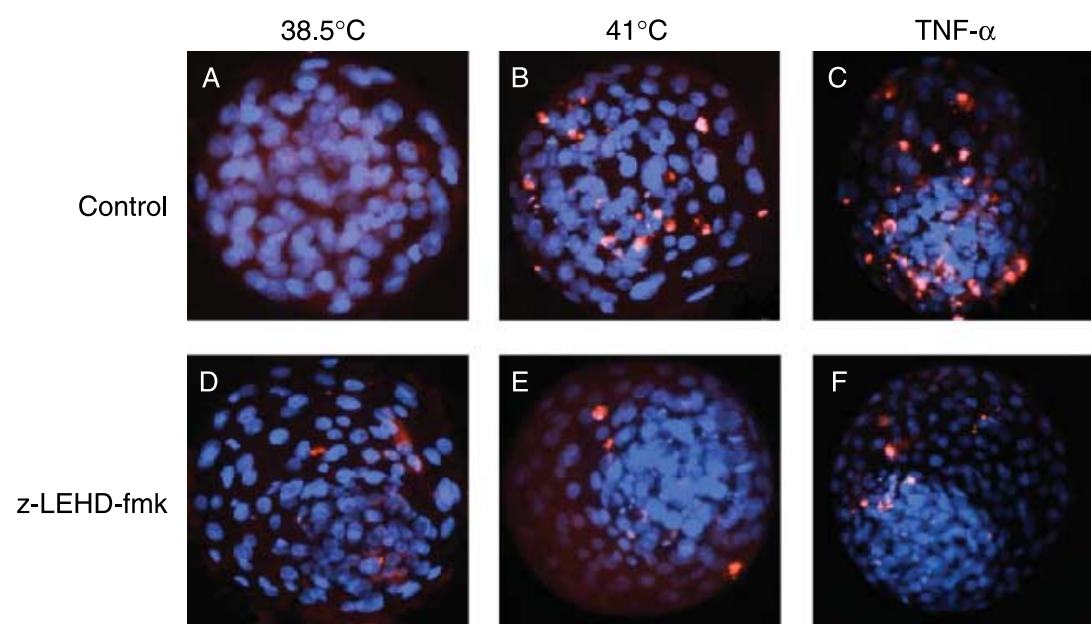

Figure 1 Representative photomicrographs illustrating the frequency of apoptotic nuclei in embryos as affected by heat shock and treatment with tumor necrosis factor- $\alpha$ (TNF- $\alpha$ ). All embryos were collected at day 6 after insemination. Detection of apoptosis was by TUNEL analysis using TMR red-conjugated dUTP to identify apoptotic nuclei (red) and Hoescht 33342 to identify all nuclei (blue). Note that exposure of embryos to $41^{\circ} \mathrm{C}$ for $15 \mathrm{~h}$ (B) and to TNF- $\alpha$ (C) increased the frequency of TUNELpositive cells when compared with embryos cultured at $38.5^{\circ} \mathrm{C}(\mathrm{A})$. In the presence of z-LEHD-fmk, however, there was no difference in TUNEL labeling between embryos cultured at $38.5^{\circ} \mathrm{C}(\mathrm{D}), 41^{\circ} \mathrm{C}(\mathrm{E})$, or with TNF- $\alpha(\mathrm{F})$. 

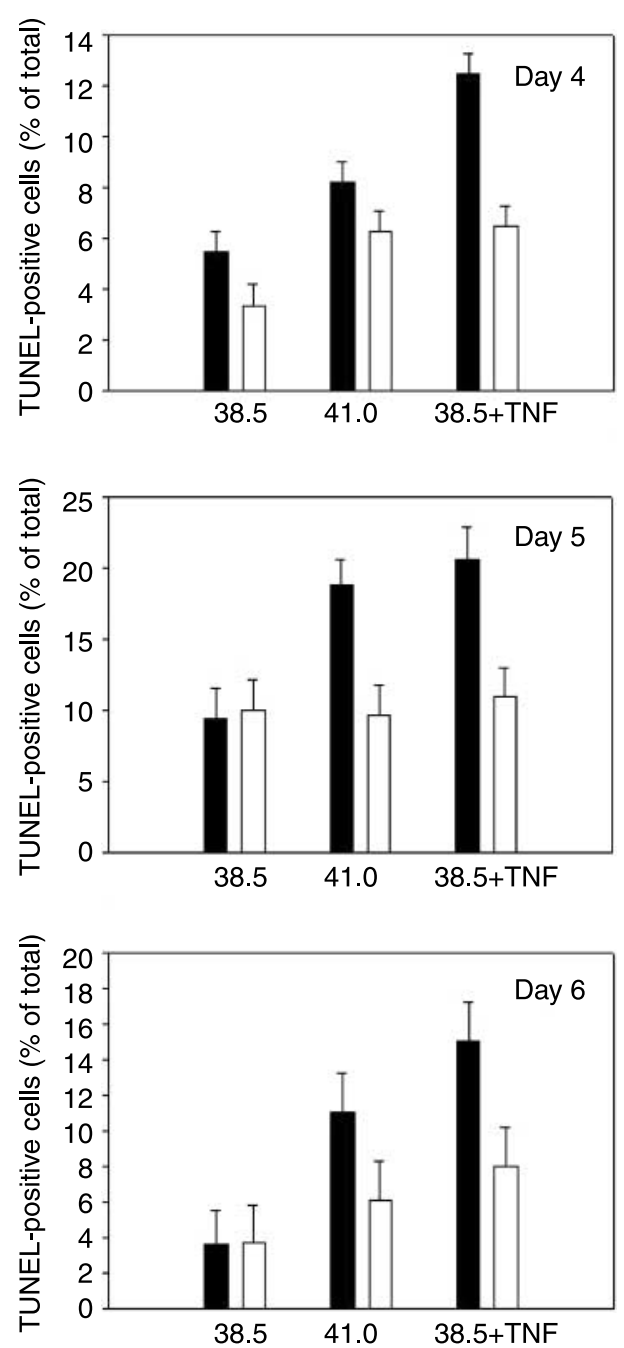

Figure 2 Induction of apoptosis by heat shock and tumor necrosis factor- $\alpha$ (TNF- $\alpha)$ in bovine embryos at days 4, 5, and 6 after insemination. Data are least-squares means \pm s.E.M. The experiment was replicated 4-5 times/day using 26-47 embryos/treatment. In embryos without caspase inhibitor (solid bars), heat shock of $41{ }^{\circ} \mathrm{C}$ for $15 \mathrm{~h}$ and TNF- $\alpha$ for $24 \mathrm{~h}$ increased the proportion of cells that were TUNEL positive when compared with embryos cultured at $38.5^{\circ} \mathrm{C}$ for $24 \mathrm{~h}$. In embryos incubated with the caspase- 9 inhibitor z-LEHD-fmk (open bars), however, there was no increase in the proportion of cells that were TUNEL positive (treatment, $P<0.001$; inhibitor, $P<0.01$; treatment $\times$ inhibitor; $P<0.05)$. There was no effect of day or interactions with day.

is a prerequisite for activation of apoptosis in preimplantation bovine embryos in response to heat shock and TNF- $\alpha$. Such a result indicates, that as for several other cells like hepatocytes (Ozoren et al. 2000, Imao et al. 2006), T-lymphocytes (Sun et al. 2002) pro-B-lymphoma cells (McDonnell et al. 2003), and colon cancer cells (Ozoren \& El-Deiry 2002), TNF- $\alpha$ induction of apoptosis in the preimplantation bovine embryo requires caspase-9-dependent pathways.

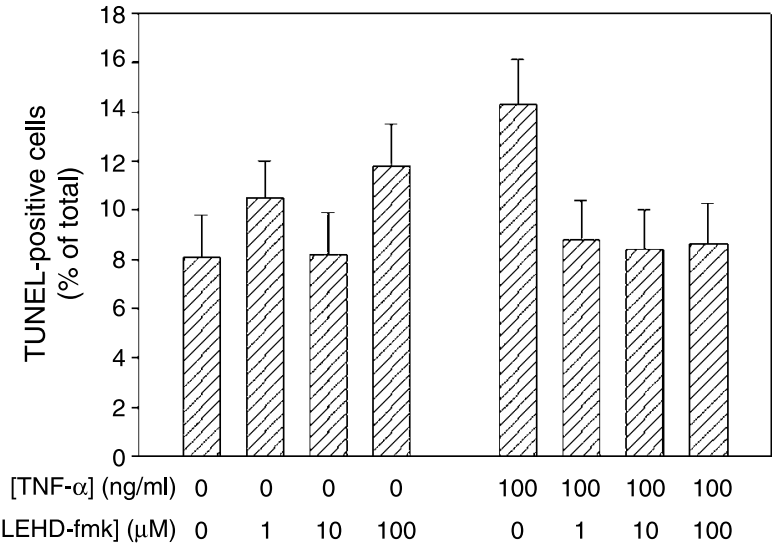

Figure 3 Effects of different concentrations of the caspase-9 inhibitor z-LEHD-fmk on apoptotic responses of embryos to tumor necrosis factor- $\alpha($ TNF- $\alpha)$. Shown are the percentage of cells that were TUNEL positive in morulae and blastocysts treated at day 6 after insemination \pm TNF- $\alpha$ in the presence of varying concentrations of $z-L E H D-f m k$. The experiment was replicated four times using 20-28 embryos/treatment. The proportion of cells labeling positive for TUNEL was affected by the TNF- $\alpha \times$ inhibitor interaction $(P<0.05)$.

That both heat shock and TNF- $\alpha$ require caspase-9 activation for induction of apoptosis is indicated by findings that 1) caspase-9 was activated by both stimuli and 2) inhibition of caspase-9 activity with z-LEHD-fmk blocked induction of apoptosis in response to both heat shock and TNF- $\alpha$. Activation of caspase- 9 activity first occurred between 3 and $6 \mathrm{~h}$ of TNF- $\alpha$ treatment, a time frame similar to the 6-12 h required for cytochrome $c$ release in pro-B-lymphoma cells following treatment with TNF- $\alpha$ and cycloheximide (McDonnell et al. 2003).

The finding that heat shock induces apoptosis through caspase-9-dependent pathways was expected because

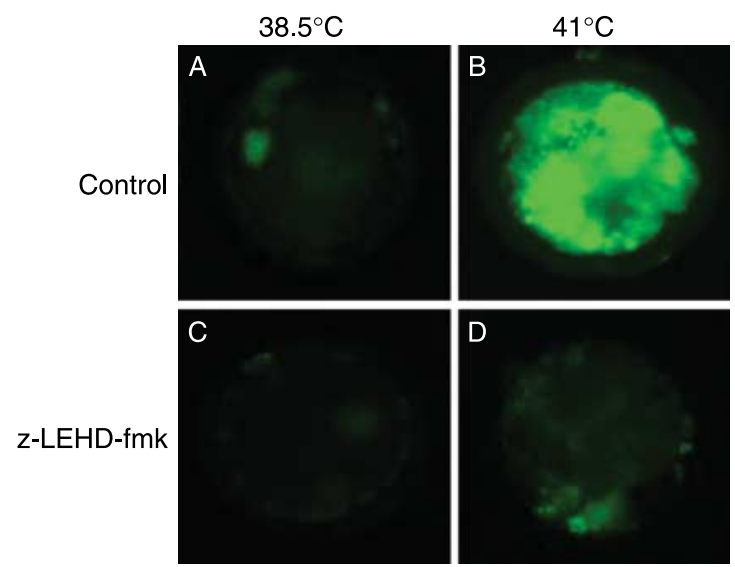

Figure 4 Representative photomicrographs illustrating induction of caspase- 9 activity by heat shock in morulae and blastocysts at day 6 after insemination. Caspase- 9 activity was determined using the fluorogenic substrate CaspaLux $9-M_{1} D_{2}$. Note that exposure of embryos to $41{ }^{\circ} \mathrm{C}$ for $15 \mathrm{~h}(\mathrm{~B})$ increased fluorescent intensity when compared with embryos cultured at $38.5^{\circ} \mathrm{C}$ (A). When embryos were cultured in z-LEHD-fmk; however, there was no increase in intensity after exposure to $41^{\circ} \mathrm{C}$ for $15 \mathrm{~h}(\mathrm{D})$ when compared with culture at $38.5^{\circ} \mathrm{C}(\mathrm{C})$. 


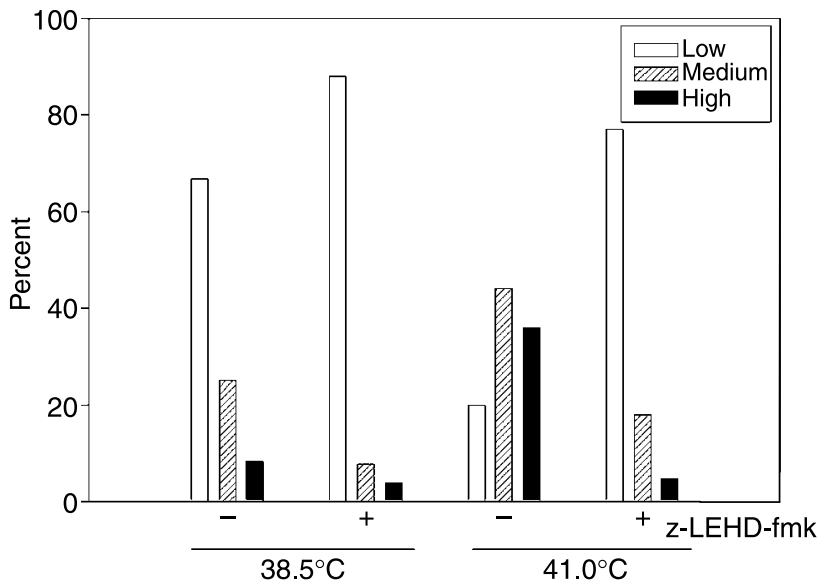

Figure 5 Induction of caspase- 9 activity in morulae and blastocysts by heat shock at day 6 after insemination. Data are expressed as the percentage of embryos displaying low, medium, or high fluorescent intensity. Embryos were cultured at 38.5 or $41^{\circ} \mathrm{C}$ for $15 \mathrm{~h}$ in the presence or absence of $100 \mu \mathrm{M} z$-LEHD-fmk. The experiment was replicated five times using 23-26 embryos per group. The distribution of embryos into fluorescence classes was affected by treatment $(P<0.05)$ and inhibitor $(P<0.001)$.

the mitochondrial pathway is the prototypical pathway for induction of apoptosis by heat shock (Mirkes \& Little 2000, Yuen et al. 2000, Little \& Mirkes 2002, Beere 2004, Bettaieb \& Averil-Bates 2005). The activation of caspase- 9 by heat shock in bovine preimplantation embryos seen in the present study is presumably the result of mitochondrial depolarization. Heat shock causes mitochondrial swelling in two-cell stage embryos cultured at 41 and $43{ }^{\circ} \mathrm{C}$ (Rivera et al. 2003, 2004).

Cells have been classified as type I or type II depending on their response to ligands such as Fas or TNF- $\alpha$ (Scaffidi et al. 1998, Sprick \& Walczak 2004). In type I cells, death receptor ligation causes formation of DISC and subsequent activation of large amounts of caspase- 8 followed by cleavage of procaspase-3 to activate caspase- 3 . In type II cells, caspase- 8 activation is reduced either because DISC formation is reduced,
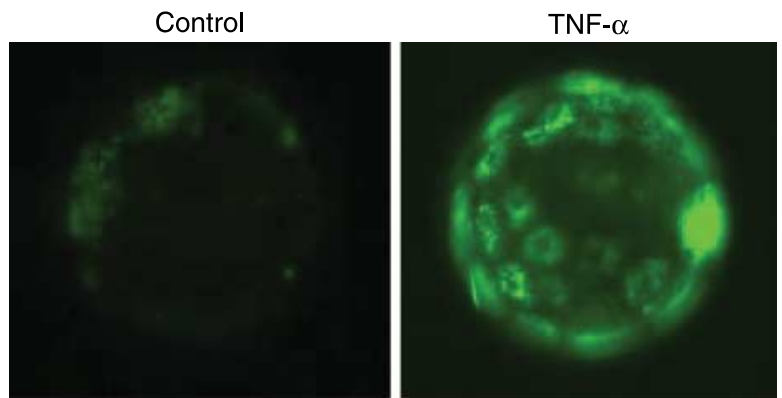

Figure 6 Representative photomicrographs illustrating activation of caspase- 9 activity in response to tumor necrosis factor- $\alpha$ (TNF- $\alpha$ ).

Shown are day 6 embryos cultured with or without $10 \mathrm{ng} / \mathrm{ml} \mathrm{TNF-} \alpha$ for $12 \mathrm{~h}$. Caspase- 9 activity was determined using the fluorogenic substrate CaspaLux $9-M_{1} D_{2}$.

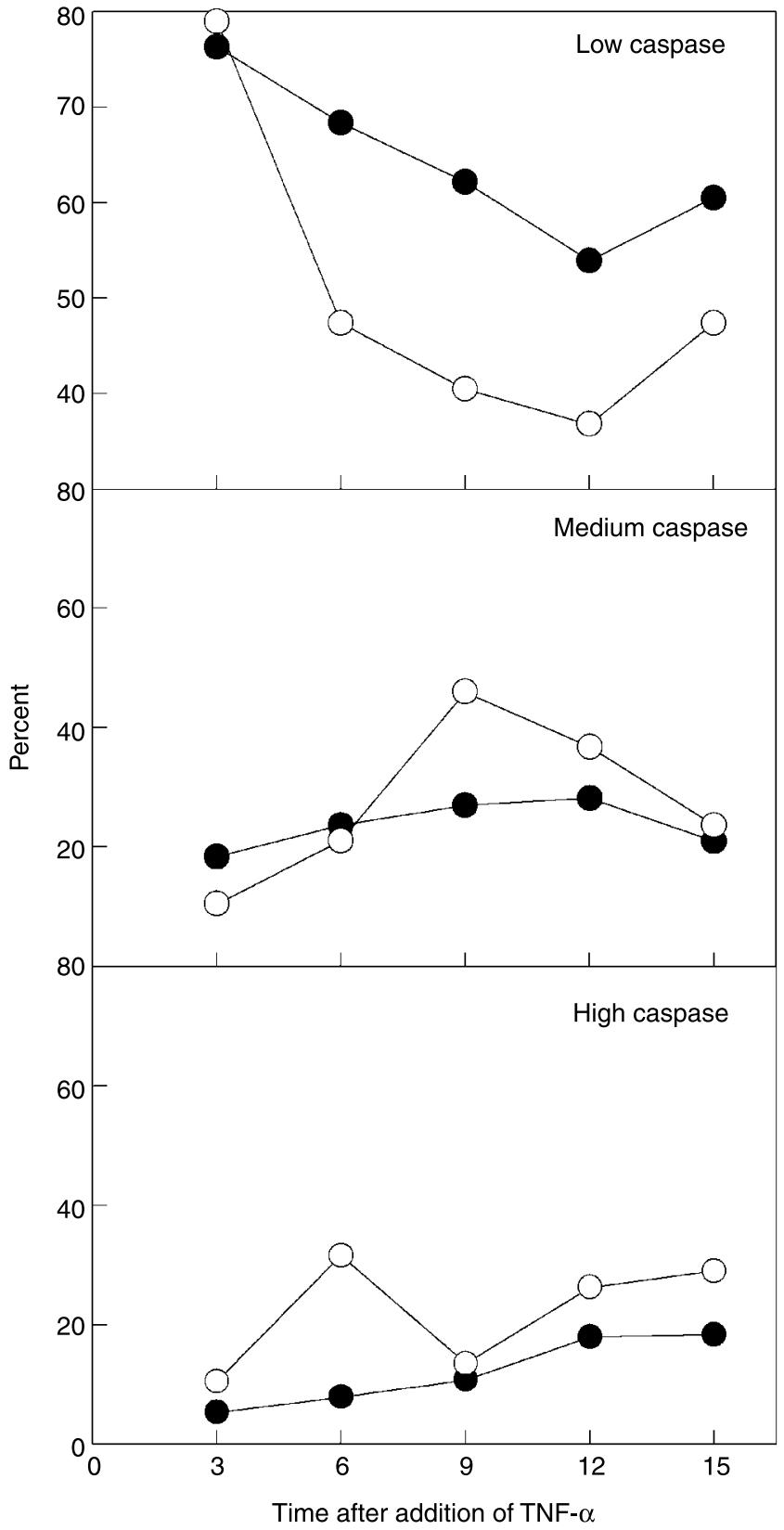

Figure 7 Time course for activation of caspase- 9 in morulae and blastocysts at day 6 after insemination in response to tumor necrosis factor- $\alpha$ (TNF- $\alpha$ ). Embryos were cultured with $10 \mathrm{ng} / \mathrm{ml} \mathrm{TNF-} \alpha(O)$ or vehicle $(\bullet)$ for various times. Caspase- 9 activity was then determined using the fluorogenic substrate CaspaLux $9-M_{1} D_{2}$. Data represent the proportion of embryos classified as having low, medium, or high caspase activity. The experiment was replicated nine times using 37-39 embryos per group. The distribution of embryos into caspase activity classes was affected by treatment $(P<0.05)$ and time $(P<0.01)$.

procaspase- 8 concentrations are low, or inhibitors to caspase- 8 activation are present in high concentrations. In type II cells, the small amounts of activated caspase-8 are sufficient, however, to induce Bid cleavage, which in turn leads to Bax and Bak dimerization, 


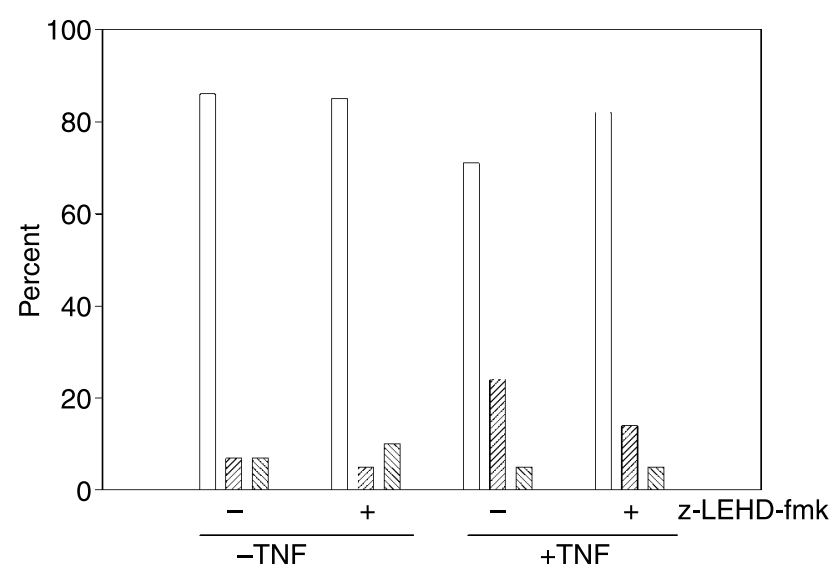

Figure 8 Caspase- 8 activity in morulae at day 5 after insemination as affected by tumor necrosis factor- $\alpha$ (TNF- $\alpha$ ). Data represent the proportion of embryos classified as having low (open bars), medium (ascending hatch), or high caspase (descending hatch) activity. The experiment was replicated four times using 14-22 embryos per treatment. There were no effects of TNF- $\alpha$ or the caspase- 8 inhibitor z-IETD-fmk on classification of embryos.

mitochondrial depolarization, and cytochrome $c$ release (Luo et al. 1998, Sprick \& Walczack 2004).

Results from the present study indicate that the bovine preimplantation embryo is a type II cell that requires caspase- 9 activation for TNF- $\alpha$-induced apoptosis. Caspase- 8 is important for activation of caspase- 9 by TNF- $\alpha$ because induction of apoptosis was partially blocked by z-IETD-fmk. The actual amount of caspase- 8 activation is likely to be low, however, because there was no detectable increase in caspase- 8 activity using the fluorogenic assay for caspase-8 employed in the present study. What is not clear is whether the activation of

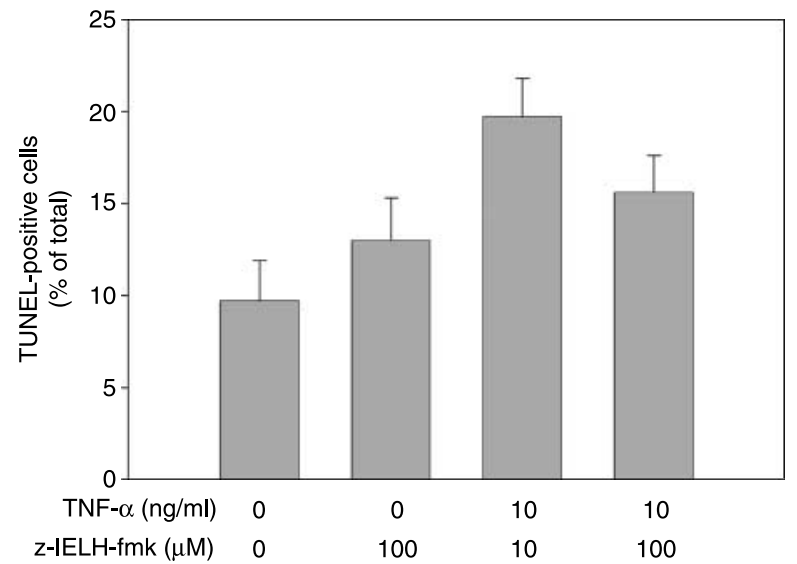

Figure 9 Induction by z-IETD-fmk of apoptosis induced by tumor necrosis factor- $\alpha$ (TNF- $\alpha$ ) in morulae at day 5 after insemination. Data are least-squares means \pm S.E.M. The experiment was replicated four times (30-35 embryos per treatment). Treatment with TNF- $\alpha$ for $24 \mathrm{~h}$ increased the proportion of cells that were TUNEL positive and this increase was partly blocked by z-IETD-fmk (treatment, $P<0.05$; treatment $\times$ inhibitor; $P=0.07$ ). caspase- 9 by TNF- $\alpha$ depends upon mitochondrial depolarization. McDonnell et al. (2003) demonstrated that combined treatment with TNF- $\alpha$ and cycloheximide induced caspase- 9 activation in pro-B-lymphoma cells even when cells were transfected with the gene for Bcl$\mathrm{xL}$ to prevent mitochondrial depolarization. Moreover, TNF- $\alpha$ induced caspase- 9 activation in murine fibroblasts with an Apaf-1 knockout phenotype (McDonnell et al. 2003). Indeed, procaspase-9 is cleaved directly by caspase-8 to caspase-9 (McDonnell et al. 2003).

Apoptosis in bovine preimplantation embryos is a developmentally regulated phenomenon. While the oocyte is capable of apoptosis in response to heat shock, at least during maturation (Roth \& Hansen 2004), the capacity for apoptosis is lost at the two-cell stage and does not become reacquired until sometime between the 8- and 16-cell stages (Byrne et al. 1999, Matwee et al. 2000, Paula-Lopes \& Hansen 2002a, Gjørret et al. 2005). In the present study, it was demonstrated that there is little change in the degree of apoptosis as embryos undergo further development from day 4 post-insemination through day 6 after insemination. This is so because the percent of cells that were TUNEL positive in response to either heat shock or TNF- $\alpha$ was similar for embryos at days 4, 5, and 6 after insemination.

Identification of the pathways through which apoptosis is induced creates the opportunity to regulate apoptosis for in vitro embryo production systems and in vivo to affect fertility. It is concluded from the present study that heat shock induces apoptosis in the preimplantation bovine embryo through a caspase-9dependent mechanism. Results are consistent with the supposition that caspase-9 activation involves mitochondrial depolarization. With respect to TNF- $\alpha$, the bovine preimplantation embryo has the characteristics of a type II cell where apoptosis involves caspase-8 mediated activation of caspase-9. Further studies are needed to define the role of mitochondria in the process of apoptosis in response to both apoptogenic stimuli.

\section{Acknowledgements}

The research was supported by Research Grant Award No. US3551-04 from BARD, The United States--Israel Binational Agricultural Research and Development Fund, and by Grant No. 2004-34135-14715 from the US Department of Agriculture T-STAR program. We thank William Rembert for collecting ovaries; Marshall, Adam, and Alex Chernin, and employees of Central Beef Packing Co. (Center Hill, FL, USA) for providing ovaries; and Scott A Randell of Southeastern Semen Services (Wellborn, FL, USA) for donating semen, and Rodrigo Nũnes de Assis for assistance during the experiments. The authors declare that there is no conflict of interest that would prejudice the impartiality of this scientific work. 


\section{References}

Beere HM 2004 'The stress of dying': the role of heat shock proteins in the regulation of apoptosis. Journal of Cell Science 117 2641-2651.

Bettaieb A \& Averill-Bates DA 2005 Thermotolerance induced at a mild temperature of $40{ }^{\circ} \mathrm{C}$ protects cells against heat shock-induced apoptosis. Journal of Cellular Physiology 205 47-57.

Byrne AT, Southgate J, Brison DR \& Leese HJ 1999 Analysis of apoptosis in the preimplantation bovine embryo using TUNEL. Journal of Reproduction and Fertility 117 97-105.

Garcia-Calvo M, Peterson EP, Leiting B, Ruel R, Nicholson DW \& Thornberry NA 1998 Inhibition of human caspases by peptide-based and macromolecular inhibitors. Journal of Biological Chemistry 273 32608-32613.

Gjørret JO, Wengle J, Maddox-Hyttel P \& King WA 2005 Chronological appearance of apoptosis in bovine embryos reconstructed by somatic cell nuclear transfer from quiescent granulosa cells. Reproduction in Domestic Animals 40 210-216.

Hansen PJ \& Aréchiga CF 1999 Strategies for managing reproduction in the heat-stressed dairy cow. Journal of Animal Science 77 (Supplement 2) 36-50.

Hansen PJ, Soto P \& Natzke RP2004 Mastitis and fertility in cattle-possible involvement of inflammation or immune activation in embryonic mortality. American Journal of Reproductive Immunology 51 294-304.

Imao M, Nagaki M, Imose M \& Moriwaki H 2006 Differential caspase9-dependent signaling pathway between tumor necrosis factor receptor- and Fas-mediated hepatocyte apoptosis in mice. Liver International 26 137-146.

Krininger CE III, Stephens SH \& Hansen PJ 2002 Developmental changes in inhibitory effects of arsenic and heat shock on growth of pre-implantation bovine embryos. Molecular Reproduction and Development 63 335-340.

Little SA \& Mirkes PE 2002 Teratogen-induced activation of caspase-9 and the mitochondrial apoptotic pathway in early postimplantation mouse embryos. Toxicology and Applied Pharmacology 181 142-151.

Luo X, Budihardjo I, Zou H, Slaughter C \& Wang X 1998 Bid, a Bcl2 interacting protein, mediates cytochrome $c$ release from mitochondria in response to activation of cell surface death receptors. Cell 94 481-490.

Matwee C, Betts DH \& King WA 2000 Apoptosis in the early bovine embryo. Zygote 8 57-68.

McDonnell MA, Wang D, Khan SM, Vander Heiden MG \& Kelekar A 2003 Caspase-9 is activated in a cytochrome $c$-independent manner early during TNF $\alpha$-induced apoptosis in murine cells. Cell Death and Differentiation 10 1005-1015.

Mirkes PE \& Little SA 2000 Cytochrome $c$ release from mitochondria of early postimplantation murine embryos exposed to 4-hydroperoxycyclophosphamide, heat shock, and storsporine. Toxicology and Applied Pharmacology 162 197-206.

Ozoren N \& El-Deiry WS 2002 Defining characteristics of Types I and II apoptotic cells in response to TRAIL. Neoplasia 4 551-557.

Ozoren N, Kim K, Burns TF, Dicker DT, Moscioni AD \& El-Deiry WS 2000 The caspase-9 inhibitor z-LEHD-fmk protects human liver cells while permitting death of cancer cells exposed to tumor necrosis factor-related apoptosis-inducing ligand. Cancer Research 60 6259-6265.

Parrish JJ, Susko-Parrish JL, Critser ES, Eyestone WH \& First NL 1986 Bovine in vitro fertilization with frozen-thawed semen. Theriogenology 25 591-600.

Paula-Lopes FF \& Hansen PJ 2002a Heat shock-induced apoptosis in preimplantation bovine embryos is a developmentally regulated phenomenon. Biology of Reproduction 66 1169-1177.

Paula-Lopes FF \& Hansen PJ 2002 b Apoptosis is an adaptative response in bovine preimplantation embryos that facilitates survival after heat shock. Biochemical and Biophysical Research Communications 295 37-42.

Rivera RM, Kelley KL, Erdos GW \& Hansen PJ 2003 Alterations in ultrastructural morphology of two-cell bovine embryos produced in vitro and in vivo following a physiologically relevant heat shock. Biology of Reproduction 69 2068-2077.

Rivera RM, Kelley KL, Erdos GW \& Hansen PJ 2004 Reorganization of microfilaments and microtubules by thermal stress in two-cell bovine embryos. Biology of Reproduction $\mathbf{7 0}$ 1852-1862.

Roth Z \& Hansen PJ 2004 Involvment of apoptosis in disruption of developmental competence of bovine oocytes by heat shock during maturation. Biology of Reproduction 71 1898-1906.

Scaffidi C, Fulda S, Srinivasan A, Friesen C, Li F, Tomaselli KJ, Debatin KM, Krammer PH \& Peter ME 1998 Two CD95 (APO-1/Fas) signaling pathways. EMBO Journal 17 1675-1687.

Soto P, Natzke RP \& Hansen PJ 2003a Actions of tumor necrosis factor$\alpha$ on oocyte maturation and embryonic development in cattle. American Journal of Reproductive Immunology 50 380-388.

Soto P, Natzke RP \& Hansen PJ 2003b Identification of possible mediators of embryonic mortality caused by mastitis: Actions of lipopolysaccharide, prostaglandin $\mathrm{F} 2_{\alpha,}$ and the nitric oxide generator, sodium nitroprusside dihydrate, on oocyte maturation and embryonic development in cattle. American Journal of Reproductive Immunology 50 263-272.

Sprick MR \& Walczak H 2004 The interplay between the Bcl-2 family and death receptor-mediated apoptosis. Biochimica et Biophysica Acta 1644 125-132.

Sun XM, Bratton SB, Butterworth M, MacFarlane M \& Cohen GM 2002 $\mathrm{BCl}-2$ and $\mathrm{BCl}-\mathrm{xL}$ inhibit CD95-mediated apoptosis by preventing mitochondrial release of Smac/DIABLO and subsequent inactivation of X-linked inhibitor-of-apoptosis protein. Journal of Biological Chemistry 277 11345-11351.

Yuen WF, Fung KP, Lee CY, Choy YM, Kong SK, Ko S \& Kwok TT 2000 Hyperthermia and tumour necrosis factor- $\alpha$ induced apoptosis via mitochondrial damage. Life Sciences 67 725-732.

Received 31 October 2006

First decision 21 December 2006

Revised manuscript received 23 January 2007

Accepted 14 February 2007 